\title{
A Humble and Meaningful Life of Commander in Chief, General Soedirman
}

\author{
Sardiman \\ Universitas Negeri Yogyakarta \\ Yogyakarta, Indonesia \\ sardiman@uny.ac.id
}

\author{
Danu Eko Agustinova \\ Universitas Negeri Yogyakarta \\ Yogyakarta, Indonesia \\ danu_eko@uny.ac.id
}

\begin{abstract}
This research aimed to: (1) identify the short biography of Soedirman, (2) describe the details about the humble life of General Soedirman, and (3) analyze the important meaning of humbleness value that had been lived by Soedirman for the civil and nation life of Indonesia. The method used in this research was critical history, which consists of five steps: topic selection, source collection, source criticism, interpretation, and historical writing. The topic selected was the humble life of Soedirman. It was interesting to study, because it presents solutive -contextual meaning. The collected sources were divided into two categories namely primary and secondary sources. The source criticisms, on the other hand, were done in two ways, namely the external criticism (to analyze the authenticity and integrity of the source) and internal criticism (to analyze the credibility of the source). In this study, interpretation is an important step to state the interrelated meaning between the facts through the analysis and synthesis as an effort to give a whole, meaningful historical construction about Soedirman's life related to his humble lifestyle. In the last step of historical writing, critical and imaginative thoughts were instrumental to build the active-dynamic historical explanation. The result of this research explains that Soedirman was grown in three sub-cultures: wong cilik, priayi, and santri. These three sub-cultures were taking part in building the character values of Soedirman, such as humbleness. This value has been implemented throughout his life. The values from his lifestyle had a connection with various values that concur with the nation's personality, Pancasila. While this can be understood that Pancasila has not been implemented consequently by the Indonesians, for example the 5th principle: "Social Justice for All Indonesians." The reality is that there are many social injustices in the country. Rich people grow richer along with their hedonistic, exaggerated and extravagant lifestyle. This kind of lifestyle is not in accordance with the spirit of Pancasila; thus, a solution is needed. The humble lifestyle practiced by Soedirman may be a model to follow and can be exemplified to overcome this problem by actualizing and socializing the value of simplicity in people's lives. If all citizens in this nation are eager to carry out a humble lifestyle, then the social injustices may gradually be overcome.
\end{abstract}

Keywords- Soedirman, Humbleness, Lifestyle, Simplicity

\section{INTRODUCTION}

It may be uncommon for some military generals to have a modest lifestyle in these times. It is because military generals in Indonesia are usually live prosperously. This study aims to depict the life of a military general, General Soedirman, who lived a simple, humble life. He is well known as the founding father of the National Army of Indonesia (Tentara Nasional Indonesia/TNI), whose humble life even got to the point of a poverty-stricken condition/mlarat. This article intentionally provides some notes and lessons for Indonesia, as the country is often reported having problems with character issues [29] and social inequity.

Indonesia is experiencing a figure crisis, facing injustice problems, as well as a loss of national pride [19]. It seems that the citizen's lives rarely represents the country's identity as a nation, which is previously known as polite, humble, cooperative, and hardworking people. Now, that character has changed toward consumptive, hedonistic, and extravagant life to the point that they fail to realize that they are violating public rights [20]. Materialism has begun to infect the citizen life, damaging the order of the civil life. For example, the rise of the "instant" culture, making shortcuts, and the unwillingness to work hard yet expecting the best result. Then it comes up to corrupted mental, dishonesty, and mentala [23] behavior (selfish). For example, the food seller that mix their product with dangerous substances in order to make the food last longer. Those kinds of sellers take a shortcut to gain as much as possible by neglecting their customers. The same kind also goes for drug dealers who profit for themselves while destroying people's life.

Besides that, in excuse of creativity, there are some people who run and name their business without concerning about ethics and morality aspects. Let's say that there are some restaurants which has name "rawon setan" (setan means devil), "es thuyul" (thuyul is an Indonesia local ghost), "mie rampok" (robber noodle) and some others. Seeing through this phenomenon in our daily lives could be hard for people who uphold the Islamic values of ethics and morality. This, as a matter of humanity has degraded 
the dignity of human as Allah SWT's most perfect being.

These phenomenon and reality that occur in daily living indicate that the noble value of Indonesia, Pancasila, has been forgotten. Pancasila is only venerated in words but is not practiced [1]. If there is no action to solve this problem, slowly but surely it will break the joints nation's lifeline. Related with this problem, this article seems appealing to be appointed as a part of the solution which is to recall and take after the values of struggle from the well-known figures that relevant with the nation's noble value. Thus, this article would appoint the notable values of General Soedirman, especially about his humbleness. The aim of this study is to: (1) know about the figure of Soedirman, (2) describe about the modest humble lifestyle of General Soedirman, and (3) analyze the essential values of modesty that General Soedirman lived towards the civil and nation life of Indonesia in this current time.

\section{METHOD}

This research is a qualitative research which employs critical history method. There are five steps in this method [15]. First, choosing the title/topic. The selection about this topic obviously related with the purpose and urgency, also the uniqueness from the subject of the study related to the topic. Secondly, the source gathering phase or heuristic as a process of inquiring the data, to find the information related to General Soedirman. Generally, historical sources divided into two types namely the primary and secondary sources. The primary source is the testimony from a subject, some witnesses, or even a mechanical object that present (and/or records) in the same period when the event occurs [10]. In this study the researcher uses several primary sources including interview results, contemporary newspaper articles, and field observation. Meanwhile the secondary source is a form of evidence that was given by someone or other sources that does not witness the historical event directly or doesn't belong to the same period with the event. For examples are books, journals, papers. After the sources compiled, the further phase is source criticism or verification. This step aimed to extract the right information from the sources and historical facts. This step consists of two criticism method. External criticism analyses about the authenticity and integrity of a source by seeing its physical form, while the internal one analyses the content's credibility of the source and its liability [24].

The fourth step is interpretation. This step is a process to assign the interrelatedness between the historical facts after going through the source criticism phase [17]. In this phase the researcher must perform some analysis and synthesis to form a whole and meaningful historical construction about the existence of Soedirman that related to his humble lifestyle. Therefore, in this phase, the study also pointed with content analysis especially those which are related to humble values and so on. Through deep analysis, this study may state about the importance of humbleness based on the Soedirman's lifestyle. It may also become a lesson and practiced in nation's life. The last phase of the research is historical writing or historiography. In this step every researcher demanded to think critically, being imaginative in order to build the historical explanation [6]. Later on the explanation is delivered in form of active-dynamic article which have dramatical power (to enhance and build emotional spirit for the readers) [16].

\section{RESULT AND DISCUSSION}

\section{A. Identifying the Figure of General Soedirman}

Speaking about Soedirman's birth and family background, several versions of story exist. According to this research and the same study by History Centre of TNI AD, Soedirman was son of a married couple, Karsid and Siyem. Soedirman was born on January 24, 1916 in Rembang village, Bodaskarangjati, Purbalingga [7]. Little Soedirman later was adopted by R. Tjokrosoenarjo (Soedirman's uncle). At that time R. Tjokrosoenarjo works as Wedana or Assistant/ District Chief in Rembang, Bodaskarangjati. $\mathrm{He}$ and his family then moved to Cilacap, where Soedirman was raised and educated by $R$. Tjokrosoenarjo's family. As a village child in his age, he participated in education programs in his village such as "ngaji" (reciting holy Qur'an). His mentor was K.H. Qahar. When he was at the age of seven, with the help of his uncle's family, Soedirman was able to take formal education in Hollandsch Inlandsche School (HIS).

Soedirman was a hardworking and diligent student. He was studious at reciting the scripture in his community as well as attending the formal school. He also often got lessons and stories about the shadow play (wayang) characters from his uncle who told him the nobility of a ksatria (knight). Soedirman's character was influenced by three different subcultures, the peasant (wong cilik) from his mother, the nobleman (priyayi) from his father, and Islamic culture (santri) from his mentors both in community and school. These three sub-cultures have given him a character which suits the community and his nationality. By the time he grew up as a teenager, he was well known as a role model in his friendship circle and even in his community.

Soedirman started and built up his leadership from the civil environment. From his study in Meer Uitgbreid Leger Onderwijs (MULO) Wiworo Tomo, Soedirman had been active in organizational activities. Besides in organization, he was also known as a persevered and tenacious student. Even among his friends, Soedirman became a role model as well as a place to ask about school lessons. Because of that, he was also known as a little teacher or teacher's 
assistant [7]. He was also a devout Moslem, compared to the students around his age. No wonder that he was called "the pious" by local youth [28].

After graduated from MULO Wiworo Tomo, Soedirman became fully involved in Muhammadiyah community circle. Firstly, he became active as a member and then showed up as a figure in Muhammadiyah scouting division named Hizboel Wathan (HW) in Cilacap. He was also an active member at Muhammadiyah youth organization (Pemuda Muhammadiyah). Later, he was also mandated to become the leader of the youth organization known as representative council of Muhammadiyah youth organization (Wakil Majelis Pemuda Muhammadiyah) in Banyumas region, and even promoted as representative for Central Java territory. His popularity rose during his career in Muhammadiyah.

The figurehead of Soedirman in $H W$ and Pemuda Muhammadiyah can be used as an indicator about his religious zeal. From a young age, he had a good understanding about the principles and teachings of Islam. Islam has become an ideology and faith that accompany his life and struggle. His knowledge of Islam then applied in his $d a$ 'wah (preaching) activity [22].

Beside a preacher, Soedirman was also an educator in HIS of Muhammadiyah. Even though he didn't have any background nor degree of teacher education, with his practical skills, he could become a professional teacher. When there was an election for principal, he was formally elected as the Headmaster of HIS Muhammadiyah in Cilacap [7]. As an educator in Muhammadiyah school, he had an idea to advance the education for the indigenous people. His nationalism spirit grew up through this education program. In many occasions when he was teaching or giving speech, he often slipped some topics related to struggles and patriotism. With his involvement as a leader of Pemuda Muhammadiyah, a da'wah specialist, and also a teacher in Muhammadiyah environment, his public persona becomes more and more steady.

During the Japanese occupation, Soedirman was already a well-known figure who concerned about his society. It was common that during this era, many people suffered due to Japanese harsh treatment. Soedirman tried to help them by establish a trading union that was called "Perkoperasian Bangsa Indonesia" (Perbi) [26]. This union eventually could ease the lives of people in Cilacap. When the Japanese government established Pembela Tanah Air (PETA), Soedirman was recruited as a battalion commander (daidancho). Through PETA Soedirman, was trained about military skills. Therefore, no wonder that Soedirman could become the leader of Badan Keamanan Rakyat (BKR/People's Security Agency), and then become the Commander of Tentara Keamanan Rakyat (TKR/People's Security Army) in Purwokerto.

After winning the Ambarawa battle against the Allies and the Netherlands, Soedirman got his reputation in the military. When TKR held an election for commander, his name was listed as one of the candidates before he was finally elected as commander of the TKR (later this, agency changed into TNI/the National Army of Indonesia). He had responsibilities to maintain the independence of Indonesia. And in cause of that responsibility, he could continue to lead the guerrilla against Dutch's military aggression in December 19, 1948, even when he was badly ill. He has offered his body, soul, and wealth to keep the Indonesian Proclamation of Independence

\section{B. Developing a Humble Lifestyle}

Soedirman was known as a humble leader. Even when he became a general, he kept his modesty. His modesty was the result of his humble lifestyle. What is the true meaning of a humble lifestyle? This kind of lifestyle is an effective and not exaggerating one. A humble lifestyle could be said as a balanced life between income and outcome [11]. God also said and ordered that human must live a humble life. As said by Surah al-Furqon, verse 67: "And [they are] those who, when they spend, do so not excessively or sparingly but are ever, between that, [justly] moderate."

According to testimony from Harsono Tjokroaminoto [12], Soedirman's attitude of simplicity and humbleness was possessed since he was a child, teenager, and to the end of his life, even when he got his position as Commander in Chief. When Soedirman has positioned as the Commander in Chief of TNI, it didn't make him forget who he really is. He kept his modesty, more trustworthy, and tend to be caring (ngemong). The term "father" for calling him and "my child" for calling his subordinates shows the emotional bond just like a nuclear family that always caring with love.

The attitude of simplicity and modesty practiced in his family life. Since he was a kid until his teenage, Soedirman usually slept on the floor with just a sheet of mat. He also practiced fasting to appreciate the weight of life. This pattern of life continued until he became the community figure, a father, and a teacher.

When leading the Pemuda Muhammadiyah Banyumas, he often went to the management office in Purbalingga. When he arrived there, he also brought some lontar leaves with him. Then he sold those leaves to surrounding residents as material to make rooftop [22]. The profit was used to raise funds or sometimes to add the household needs. His life improved a bit when he became the headmaster of 
HIS Muhammadiyah in Cilacap. But he kept his modest lifestyle.

At that time in Banyumas, when there was a local feast, it always be a massive event with the reason to keep the praja (self and family pride). Therefore, in many preaching occasions, Soedirman often criticize those kinds of excessive, wasteful lifestyle. He did give warnings, many times that it is important to live a simple and humble life, and not being wasteful

Through his humorous sarcasm, Soedirman spoke his critic about the lifestyle in his society. He explained that the family which held the feast would soon face the four ma i.e.: makuthi, makuthem, makutha, and makethetheran. Makuthi means that before the feast began, they would prepare money and stuffs for the feast. Makuthem means the closer the day to the feast, the tighter the budget would be. Makutha means, when the feast began, everyone is happy, and the feast holder was like a king because every friend and society around them are serving the family. Makethetheran means that after the feast ended, the feast holder started to calculate their profit and loss, and usually it's more the loss than the profit. They were all out, and often charged with debts. The economic problem of the family would like to continue. Back with his sarcastic joke, Soedirman than warned that if the debts were closing in, the family would likely to find sapi ilang or kebo ilang (losing cattle) and worse would be wisma ilang (losing the house). If those things happened, a man cannot live his quality life anymore.

The attitude and humble lifestyle kept engraved in Soedirman's life and his family. Even when he became a high official, he never has a thought to enrich himself nor his family. He was struggling selflessly, especially for the benefit of the nation and state. If previously was said that humble lifestyle is all about the balance of income and outcome, materially, his live was often below those standards. It was because almost half of his family property used to support the struggle for Indonesian independence. Even Colonel Soegiri (at the time was a First Lieutenant, Soedirman's former adjutant) said that Soedirman was a poor general. Then, de explained that when Soedirman died, his wife was unable to guest the mourners properly. She was looking for loans to the neighborhood. Even, according to the testimony of Atjeng Soehanda and Chief Warrant Officer Abdoelrozak, one day, Soedirman's wife was unable to give dishes to her kids that she then poured the plain rice with tea.

Thus, the lifestyle of Soedirman was known as a general who lived a humble life, hardworking and discipline. It needs to be underlined that humble lifestyle requires a capability of self-control to maintain the balance and to limit themselves. In this context, the humble lifestyle is related to discipline attitude. Discipline id a kind of behavior that driven by conscience and norms or terms, so that someone can obey to do what supposed to do and able to control himself from things deemed deviant. In other words, a discipline person obeys and carry out the rules and norms. This attitude is also related with hardworking which means that every task and rules should be done without delay.

Although he grew up in priayi family, Soedirman still showed his humble, nice and hardworking attitude. He usually helped the house by doing chores, since he was a child. When he got older and involved in HW as a leader, he mentored his members in scouting programs seriously. The same goes when he was assigned as Pemuda Muhamadiyah Banyumas, he often got home at late night, so that he started losing weight. He did that for the sake of the organization.

His hard-working ethic also clearly seen in Soedirman's days of involvement and struggle to help others from the Dutch's harsh treatment. When the Japanese came to occupy, Soedirman had a hard time struggling to help the poor who suffered from famine by forming Badan Pengurus Makanan Rakyat (BPMR or Public Food-Serving Committee). Along with this committee Soedirman had to travel around the districts that struck by hunger. When he became the Commander of PETA, he worked more carefully to quell the PETA Gumilir rebel led by Budancho Kusaeri.

The peak of hard work and discipline of Soedirman was shown when he took responsibility as Chief Commander of TKR. Shortly after, he led a guerrilla campaign and faced various problems. For examples, when he became the member of Ceasefire Committee, when he led the battle of Ambarawa, when faced the Dutch first military aggression, and when he crushed the FDR-PKI rebellion 1948. After all of those problems, he had to be hospitalized in Yogyakarta due to tuberculosis [30]. Even he had his right lung removed [28].

During the treatment at the hospital, as a commander, Soedirman cannot leave his task. Even in his bad condition he always asked field reports from his aide, his guard, and from the field commanders. Based on those reports, he could make strategical moves. Even, he knew that the Netherlands would soon carry out next aggression. Therefore, Soedirman forced himself to leave the hospital. Under supervision of a doctor, asked for permission get house rest in Bintaran [28]. While taking a break at his house, he continued to monitor the political conditions in Indonesia which grew alarming.

Hearing a report from his subordinate, T.B. Simatupang, Soedirman who for a few days laid on bed miraculously rose and declared that he had taken back the leadership of the Indonesian Armed Forces. His affirmation was announced to various directions to raise the morale and fighting spirit of the entire command unit of the TNI soldiers [31]. 
Soedirman's assumption was correct because the Dutch eventually launched their second aggression on December 19, 1948. With his military instinct, Soedirman was not gave up. He chose to take guerrilla campaign. With only one lung, Soedirman and some of his bodyguards left central Yogyakarta. Enthusiastically, Soedirman waged the spirit of jihad to lead the war against the Dutch as a tyrant invader. Therefore, the Netherlands must be fought to the death. Together with his bodyguards, Soedirman continued to wage the war by moving into the forests. Those obstacles did not discourage him from continuing to pump up the fighting spirit of his soldiers on the battlefield. After going through a route around 1009 kilometers long for around half a year [9], finally he ended his guerrilla campaign. He went back to the Capital of Indonesia in Yogyakarta after the Ducth left.

That is the picture of Soedirman's modest life. In his simplicity, Soedirman was inseparable from the life full of discipline, responsibility and hard work. These values have been inscribed on General Sudirman.

\section{The Meaning of Humbleness Value}

General Soedirman with his modest life may become example for the people in our time. These simplicity values are very important values in the life of society and nation. A simple lifestyle is always related to many relevant values of Indonesia, the Pancasila.

The pattern of life and the simplicity are also related to the value of devotion. Because in the practice of a simple lifestyle like what Soedirman lived, it meant that what he did was the order from God. A simple lifestyle is an aspect of self-control for not being extravagant. As already stated in Sura AlFurqan verse 67 it, has been ordered that humans are prohibited to be excessive and not miserly in spending/infusing their properties. Because it involves the command of God, a simple lifestyle can be related to the value of devotion and the value of Deity (1st principle of Pancasila).

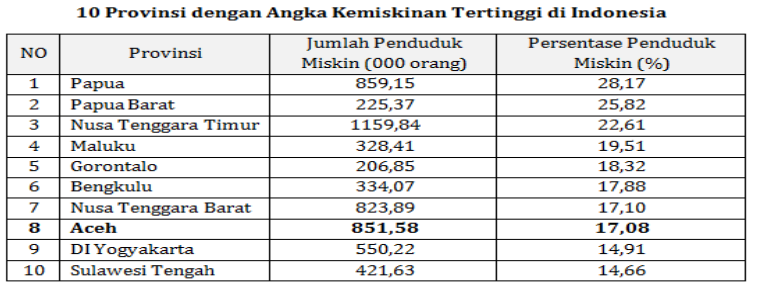

*Data diolah dari Laporan Sosial Ekonomi BPS November 2015.

Fig. 1. List of 10 poorest provinces in Indonesia [3]

Living a simple life is a self-control, not being greedy but just enough. The process of self-control for not being greedy but accepting just enough is closely related to the attitude of always being grateful. Along with being humble and grateful attitude, there would come a desire to share will bear qana' $a h$ attitude. This attitude will always accept what it is, being thankful and accepts what God has predestined for him.

The concept of a simple lifestyle closely related to behavior of not being excessive and extravagant; sincere and grateful; empathy and sharing spirit; which is also related very close to the concept and value of justice. Someone will only take what is really needed. This, indirectly gives the opportunity for others to take part in having goods and services or everything that is needed (there is an element of sharing with others, not being greedy to themselves). Thus, the simple lifestyle is also close to equality.

Other concept that is related to simplicity is fairness. Fair (adil) comes from the Arabic word: $a d l$, which means the same, equal, flat, the middle of the matter. The concept of equal and commensurate is often associated with things that are non-material. Therefore, the concept of fairness does not have to be numerically equal. In Christian philosophy there is a saying about the meaning of equality as follows: "Do not do to others something we are not happy, if someone else does it to us [11]." Prophet Muhammad SAW taught about equality as follows: "one's has no faith before he loves his brothers and sisters as he loves himself." From the illustration it can be emphasized that equality is when each person feels something in common, if one is happy the other must also be happy, if sad, the sadness should be felt by the others. Equality is also related to the principle of balance. Fair for one's self, how a person's lifestyle can balance between his rights and obligations. This conception of fair value is certainly in accordance with Pancasila, the 5th principle.

Considering the above description, it is conceptually clear that the humble lifestyle has relevance to the values of Pancasila, either the 1st, 2nd, 3rd, 4th and 5th precepts. This goes in sync with the ideological conception that the Pancasila which consists of the five precepts is a unity which cannot be separated. However, if we carefully examined, given the weight of the direct and indirect levels, this humble lifestyle is more directly related to the 5th principle, namely the "Social Justice for All Indonesian People" precepts.

Speaking of the 5th precept, in the context of this article it becomes very interesting. In various talks and discussions of some circles, these precepts are not getting enough attention. A criticism was once made by A. Syafii Maarif that the 5th principle of Pancasila is often ignored. "Even if the infrastructure is adequate, human resources are on high quality, but if the application of the fifth precept, the "Social Justice for All Indonesian People "is ignored, it is such as betrayal to the state [2]." This can be demonstrated, for example, there are still many Indonesians who live 
below the poverty line and there's still a wide gap between the rich and the poor. In Indonesia, the number of poor people is almost evenly distributed in various regions in Indonesia. As an illustration of the poverty rate, the following information presents 10 provinces that have the poorest population in Indonesia.

According to the Central Statistics Agency (BPS) per September 2015, the number of poor people in Indonesia reached 28.51 million people (11.13\%), after the agency used the poverty line of IDR 344,809 per capita per month. This poverty rate is certainly quite alarming, plus the wide gap of inequality between the rich and the poor. In 2014 the inequality was at $0.41 \%$ and reached $0.42 \%$ in 2015 [21]. This gap rate is mentioned as the highest level in history in Indonesia. This illustrates one of the portraits of injustice in Indonesia. That is, economic growth is only enjoyed by the upper middle class, while the lower middle class are getting worse. But in September 2017 the gap rate improved a bit at $0.391 \%$. Even though it has experienced a slight decrease in the number of disparities, the difference between the rich and the poor still clearly visible. Darmin Nasution, when served as Coordinating Minister for Economic Affairs also reported, that economic growth continued to improve but had not been able yet to correct the problem of social inequality in the community [4] Therefore, of course there are reasons why the gap is still widening, the difference between the rich and the poor become more visible, even though the economic growth rate is getting better. The factor that causes social inequality keep widening is because of the increasingly widespread hedonism, extravagance, and luxurious lifestyle. Those who tend to be luxurious are only a small group but control the economic power of the community. While the majority belong to the lower middle class in which there are many poor people (according to BPS data in September 2017 the poor population is 26,58 million people) which according to Clifford Geertz that group would remain involutional [5]. Besides the poor population itself there are also large group of people who have the potential to fall into poverty.

The fact is that life concept in Indonesian society and nation is strongly influenced by materialism cultures such as a consumptive and hedonic lifestyle. As a result, in their daily lives those who embrace this lifestyle often take other people rights as a consequence of their lifestyle. For example, a family that possess two or more cars, when they all come out, they may take responsibility of the traffic jams.

Not only that, community members can also be a jerk to give themselves a bigger profit. It doesn't matter if other people are being harmed, if they got their benefits (the mentala attitude). For example, many food sellers, vegetables, or fruits that mixed their goods with strong preservatives that may being hazardous to the people/buyers who eat their product. Harming other people is a despotic act.

Those illustrations above may tell us that materialism with a consumptive and hedonistic lifestyle may encourages people to behave unethically, act unjustly to the others, and demean human dignity as God's most perfect. In fact, it must be realized that consumptive and hedonic lifestyles may also encourage violent behavior, drug addiction, and corruption tendencies. The honesty inside a person begins to cripple because it is corrupted by materialism and consumerism.

Thus, such culture has encouraged the tendencies on taking backdoors (examples have been referred to as corruption, being a drug dealer, dishonest trade to gain bigger profit, to be pimps, etc.). Everyone wants to get rich quickly, wants everything at their own will, and don't want to work hard. Community life tends to be pragmatic, oriented to physical-material matter, and pursuing momentary satisfaction [13]. This way of life is totally irrelevant with the basic values of Pancasila. It does not relevant with the value of cooperation, togetherness, and not in line with democracy by the basis of deliberation and the principle of kinship. It also contrary to the values of social justice. Not only contradicts the values of the Pancasila but it also against the religious teachings. Therefore, this lifestyle has become a social illness. This bad lifestyle can't be separated from the strong influence of the capitalist economy in Indonesia [25].

How to prevent and control this negative lifestyle? It seems that the humble lifestyle of Soedirman as explained before needs to be actualized and socialized in the society. Exemplifying the humble lifestyle that General Soedirman has lived is the right and important step to be taken. Actualizing the value of simplicity that had been "taken" by him can become a "cure" to overcome various problems of such materialistic lifestyles. Especially if the simple lifestyle is combined with discipline and hard work attitude.

Discipline is a behavior of stick to the rules or norms that apply and is done sincerely. Therefore, the real discipline is someone's obedience to carry out the rules sincerely because he is guided by conscience. Sincerity in carrying out the rules and the ability to control themselves not to deviate from this norm requires serious work.

The implementation of this discipline value will give birth to an orderly life. Living in an orderly manner will give birth to the ease of carrying out activities. An orderly community life will give birth to a safe and peaceful community life. Because everything is easy and the condition is safe, the community will be happy, far from stress, and then it leads to pleasure. Thus, people's lives will become more productive. In the context of social life, a 
disciplined life will give birth to an orderly society which will lead to a safe and peaceful society.

From the description above, it can be emphasized that people who practice humble lifestyle supported by both discipline and hard work attitude will build a dignified society. Because the community is always grateful, empathetic, eager to share, and peaceful, subsequently they become more productive in building a more prosperous life. With productivity in the community, it can overcome social inequality. Especially if a simple lifestyle is successfully actualized in the life of society and nation, it will create justice and prosperity of life in the existing society.

\section{CONCLUSION}

Based on the results of the research and the discussion about the meaning of the humbleness value practiced by Soedirman, it can be concluded as follows.

1. Sudirman has a unique family background. He came from the family of ordinary people and was adopted by a sub-district head of RembangPurbalingga, R. Tjokrosoenarjo (his uncle). Soedirman grew in three subcultures: wong cilik, priayi, and santri. These subcultures had formed Soedirman with characters such as, humble and hard-working; polite and have a heroic spirit; and pious. He was active in the Muhammadiyah association, as the HW commander and as the Muhammadiyah youth leader in Banyumas. He is also an educator, head of the Muhammadiyah HIS school in Cilacap, and a missionary interpreter who is very popular in the community. During the Japanese occupation Sudirman entered Peta and was finally trusted as a commander. His experience in the military sector also grew well. After Indonesia entering independence era, Soedirman was appointed as Commander of TKR and finally was elected as the Commander in Chief of TKR / TNI.

2. Soedirman was a person who always lived a simple life, full of discipline and hard work. Since he was a teenager, he had practiced fasting, diligently worked both in the family, community activities and organizational duties, especially after being trusted as a leader. He tried to work hard to provide good service for the members of organization.

3. A humble lifestyle has an important meaning in the life of society and nation. Simple lifestyle that was taken by Soedirman was related to various values relevant to the values of Pancasila. Meanwhile, the precepts of Pancasila have not been widely practiced. In the words of A. Syafii Maarif, Pancasila is only glorified in words. As an example, the implementation of the fifth principle which stated about social justice for all Indonesian is still far from reality. Social inequality is still a problem. This happens because the rich tends to live extravagant life, which is against the values of Pancasila. Meanwhile, not much can be done by the poor. Thus, a simple lifestyle supported by the attitude of discipline and hard work as lived by Soedirman can be used as a model and to organize a better life.

\section{REFERENCES}

[1] Ahmad Syafii Maarif. Titik-titik kisar di perjalanan, aotobiografi, Bandung: Kerjasama Mizan dan Maarif Institute, 2009

[2] --------, (2016). "Sila kelima Pancasila sering diabaikan," Kedaulatan Rakyat, 24 Mei 2016.

[3] Badan Pusat Statistik, November 2015

[4] Badan Pusat Statistik, September 2017

[5] Bambang Rustanto, Menangani kemiskinan. Bandung: PT Remaja Rosdakarya, 2015.

[6] Berkhofer, Robert F, A behavioral approach to historical analysis. New York; the Free Press.

[7] Dinas Sejarah TNI AD, "Sudirman prajurit TNI teladan," Jakarta: Dinas Sejarah TNI AD, 1985.

[8] Djoko Dwiyanto, \& Ignas G. Saksono, "Ekonomi (sosialis) Pancasila vs kapitalisme: nilai-nilai tradisional dan nontradisional dalam Pancasila, Yogyakarta," Keluarga Besar Marhenisme DIY, 2010.

[9] Firdaus Ubaidillah, "Napak tilas atau penjelajahan rute gerilya Panglima Besar Jenderal Soedirman," downloaded at 10 Juli 2018

[10] Gottschalk, Louis "Mengerti sejarah," Jakarta: UI Press, 1989.

[11] Hamka, "Filsafat hidup: memecahkan rahasia kehidupan berdasarkan tuntunan Al-Qur'an dan As-Sunnah" (editor Muh. Iqbal Santosa), Jakarta: Republika, 2015.

[12] Harsono Tjokroaminoto, "Seri penerbitan sejarah lisan," No.2., Menelusuri jejak ayahku, Jakarta: Arnas, 1983.

[13] I Gde Widja, "Menuju wajah baru pendidikan sejarah," Yogyakarta: Lapera, 2002.

[14] Ilyas Ismail, A "Pilar-pilar takwa: doktrin, pemikiran, hikmat, dan pencerahan spiritual," Jakarta: Rajawali Pers, 2009.

[15] Kuntowijoyo, (Peny) "Sejarah perjuangan Hisbullahsabilillah divisi Sunan Bonang," Yayasan Bhakti Utama, Surakarta dan MSI Cabang Yogyakarta, 1997.

[16] McCoy, F.N. "Researching and writing history: a practical handbook for students," Los Angeles: University of California Press, 1974.

[17] Nugroho Notosusanto, Sejarah demi masa kini, Jakarta: UI Press, 1979

[18] Julius Pour, Doorstoot naar Djokja: pertikaian pemimpin sipil-militer, Jakarta: Kompas, 2009.

[19] Mochtar Buchari, Pendidikan antisipatoris, Yogyakarta: Kanisius, 2001.

[20] Rumah Suluh, "Kembali pada tinjauan kemerdekaan bangsa", dalam: Kembali kepada jati diri bangsa, Yogyakarta: JECKedaulatan Rakyat-Universitas Janabadra, 2013

[21] Said Iqbal, "Angka kesenjangan ekonomi di Indonesia meningkat." 2015.

[22] Sardiman AM., Sudirman kader Muhammadiyah, Yogyakarta: Adicita, 2000.

[23] Sjafri Sjairin, "Isu-isu penelitian sosial: perubahan sosial budaya”, Makalah: disampaikan dalam acara diskusi Fistrans, Yogyakarta: FIS UNY, 26 Mei 2015.

[24] Shafer, Robert Jones, et.all, A guide to historical method, Illinois: The Dorsey Press, 1980.

[25] Soepriyatno, Nasionalisme dan kebangkitan ekonomi, Jakarta: INSID Press, 2008.

[26] Solichin Salam, Jenderal Sudirman pahlawan kemerdekaan, Jakarta: Jayamurni, 1963. 
[27] Sulistyo Atmodjo, S., Mengenang almarhum Panglima Besar Jenderal Soedirman: pahlawan besar, Jakarta: Yayasan Panglima Besar Jenderal Besar Soedirman, 1991.

[28] Soekanto, Perjalanan bersahaja jenderal Sudirman, Jakarta: Pusaka Jaya, 1981

[29] Susilo Bambang Yudhoyono, Media Indonesia, 11 Juli, 2010.
[30] Tarjo, Dari atas tandu pak Dirman memimpin perang rakyat semesta, Yogyakarta: Yayasan Wiratama 45, Angkasa Offset, 1984.

[31] Tjokropranolo, Panglima Besar TNI Jenderal Sudirman pemimpin pendobrak terakhir penjajahan di Indonesia, Jakarta: P.T. Surya Persindo, 1992. 